groups of men non-employed through illness are likely to be heterogeneous with regard to type and severity of illness. Thus for some men, but not all, illness will be directly responsible for their weight loss and reduction in smoking and drinking.

This study indicates the need to take account of the long term effects of higher levels of smoking and alcohol consumption and less exercise before unemployment when comparing mortality and morbidity among groups of unemployed and employed people, such as in the Office of Population Censuses and Surveys longitudinal study.

The British Regional Heart Study is a British Heart Foundation research group. It is also supported by the Department of Health and the Chest, Heart, and Stroke Association. JKM was supported by a special project grant from the Medical Research Council.

1 Office of Population Censuses and Survevs, Social Survey Division. General household survey, 1980. London: HMSO, 1980

2 Office of Population Censuses and Surveys, Social Survey Division. General household survey, 1982. London: HMSO, 1984.

3 Office of Population Censuses and Survers, Social Survey Division. General household survey, 1984. London: HMSO, 1986.

4 Office of Population Censuses and Surveys, Social Survey Division. General household survey, 1986. London: HMSO, 1988

5 Office of Population Censuses and Surveys, Social Survey Division. General household survev, 1988. London: HMSO, 1990.

6 Crawford A, Plant MA, Kreitman N, Latcham RW. Unemployment and drinking hehaviour: some data from a general population survey of alcohol use. Br f Addiction 1987:82:1007-16.

$7 \mathrm{~K}$ eser RC. House JS, Turner JB. Unemployment and Health in a community sample. F Health Soc Behav 1987;28:51-9.

Cook DG, Cummins RO, Bartlet MJ, Shaper AG. Health of unemploved middle-aged men in Great Britain. Lancet 1982:i:1290-4.

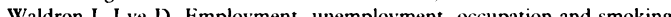
Am $\mathcal{P}$ Prev $\mathrm{Med} 1989 ; 3: 142 \cdot 9$.

10 Lee AJ, Crombic IK, Smith WCS, Tunstall-Pedoe H. Alcohol consumption and unemployment among men: the Scottish heart health study. $\mathrm{Br} f$ and unemployment amon

11 Shaper AG, Pocock SJ, Walker M, Cohen NM, Wale CJ, Thompson AG. British regional heart study: cardiovascular risk factors in middle-aged men in 2+ towns. BMF 1981;283:179-86
2 Office of Population Censuses and Surveys. Classification of occupations, 1970. London: HMSO, 1970

13 Bray GA. Definition, measurement and classification of the syndromes of obesity. Int 7 Obes 1978;2:99-112.

14 Narendranthan $W$, Nickell $S$, Metcalf $D$. An investigation into the incidence and dynamic structure of sickness and unemployment in Britain, 1965-75. Journal of the Royal Statistical Society (America) 1985;148:254-67.

15 Cummins RO, Shaper AG, Walker M, Wale CJ. Smoking and drinking by middle aged British men: effects of social class and town of residence. $B M$ $1981 ; 283: 1497-502$.

16 Wilcosky $\mathrm{T}$, Chambless $\mathrm{L}$. A comparison of direct adjustment and regressio adjustment of epidemiologic measures. $\mathcal{F}$ Chronic Dis 1985;38:849-56.

17 Hosmer D, Lemeshow S. Applied logistic regression. New York: Wiley, 1989.

18 SAS Institute. SUGI supplemental library user's guide. Version 5. Carey, North Carolina: SAS Institute, 1986

19 SAS Institute. SAS user's guide: statistics. Version 5. Carey, North Carolina: SAS Institute, 1985.

20 Wannamethee G, Shaper AG. Body weight and mortality in middle aged British men: impact of smoking. $B M \mathcal{F}$ 1989;299:1497-502.

21 Hammerstrom A, Janlert U, Theorell T. Youth unemployment and ill health: results from a 2-year follow-up study. Soc Sci Med 1988;26:1025-33.

22 Kirby HD, Luker KA. The experience of unemployment and its effects on family life. Health Visitor 1986;59:312-4.

23 Heady $\mathrm{P}$, Smith $M$. Living standards during unemployment. London: $\mathrm{HMSO}$ 1989.

24 Iversen $\mathrm{L}, \mathrm{Klausen} \mathrm{H}$. Alcohol consumption among laid-off workers before and after closure of a Danish ship-yard: a 2-year follow-up study. Soc Sci Med 1986;22:107-9.

25 Warr $P$, Payne R. Social class and reported changes in behaviour after job loss. fournal of Applied Social Psychology 1983;13:206-22.

26 Smart RG. Drinking problems among employed, unemployed and shif workers. F Occup Med 1979;21:731-6.

27 Kendell RE, de Roumanie M, Ritson EB. Influence of an increase in excise duty on alcohol consumption and its adverse effects. $B M \mathcal{F}$ 1983;287:809-11.

28 Palta M, Prineas RJ, Berman R, Hannan P. Comparison of self-reported and measured height and weight. Am $\mathcal{F}$ Epidemiol 1982;115:223-30.

29 Kasl SV, Cobb S, Gore S. Changes in reported illness and illness behaviour related to termination of employment: a preliminary report. Int $\mathcal{F} E$ pidemi 1972;1:111-8.

30 Mattiasson I, Lindgarde F, Nilsson JA, Theorell T. Threat of unemploymen and cardiovascular risk factors: longitudinal study of quality of sleep and serum cholesterol concentrations in men threatened with redundancy. $B M \mathcal{J}$ 1990:301:461-6.

31 Wannamethee G, Shaper AG. Weight change in middle-aged British men: implications for health. Eur $\mathcal{Y}$ Clin Nut 1990;44:133-42.

32 Shaper $\mathrm{AG}$, Wannamethee $\mathrm{G}$. Physical activity and ischaemic heart disease in her AG, Wannamethee G. Physical activity and isc

33 Moser KA, Fox AJ, Jones DR. Unemployment and mortality in the OPCS longitudinal study. Lancet 1984;ii:1324-8.

(Accepted 4 December 1991 )

列

\title{
Relation of bronchioloalveolar carcinoma to tobacco
}

\author{
Alfredo Morabia, Ernst L Wynder
}

Abstract

Objective-To determine whether bronchioalveolar carcinoma is related to tobacco use.

Design-Case-control study.

Setting-11 teaching hospitals of Chicago, Long Island, New York, and Philadelphia, 1977-89.

Subjects -87 patients with histologically diagnosed bronchioloalveolar carcinoma (cases) and 286 non-cancer and 297 cancer patients matched to admission.

Results $-10 \%$ of male cases and $25 \%$ of female cases had never smoked. Relative risks of bronchioloalveolar carcinoma (as estimated by the relative odds) were greater for subjects who started smoking at a younger age, smoked for a longer time, or smoked more cigarettes per day. Relative risks decreased proportionally to the duration of smoking cessation.

Conclusion-Smoking plays an important part in the aetiology of bronchioloalveolar carcinoma but is not the only potential cause because of the large proportion of never smokers among patients with this disease.

Correspondence and requests for reprints to: Dr Ernst L Wynder, American Health Foundation, 320 E43rd St, New York, NY10017, USA

BM 1992;304:541-3 Introduction

Bronchioloalveolar carcinoma is a well differentiated adenocarcinoma growing as a single layer of malignant cells within the alveolar space. ${ }^{12}$ It is generally cases on age, sex, race, hospital, and date of

accepted that bronchioloalveolar carcinoma is clinically and pathologically distinct from other cell types of lung cancer. ${ }^{34}$

Current knowledge of the role of tobacco smoking in the aetiology of bronchioloalveolar carcinoma originates from series of patients with lung cancer that showed a higher proportion of non-smokers among patients with bronchioloalveolar carcinoma than other lung cancer cell types. ${ }^{3-8}$ To our knowledge, though, there are no cohort or case-control series that formally determined the relation of bronchioloalveolar carcinoma and tobacco smoke. The resulting impression is that smoking is unimportant in the aetiology of bronchioloalveolar carcinoma. ${ }^{9}$

Between 1977 and 1989, 87 patients with histologically confirmed bronchioloalveolar carcinoma were interviewed in the longstanding case-control study of tobacco related diseases conducted by the American Health Foundation. This offered an opportunity, using a rigorous epidemiological design, to determine whether cigarette smoking is related to bronchioloalveolar carcinoma.

\section{Methods}

The present data come from the hospital based case-control study of the American Health Foundation that has been described in detail elsewhere. ${ }^{10}$ Between 1977 and 1989, 4913 patients with lung cancer were interviewed in 11 teaching hospitals in Chicago, Phila- 
delphia, New York, and Long Island. Of these 4913 patients with lung cancer, $107(2 \%)$ were coded as having bronchioloalveolar carcinoma, but copies of only 92 original pathology reports were obtained. Of these 92 potential cases, five were not retained because the final pathological diagnoses were adenocarcinoma $(\mathrm{n}=3)$, squamous cell carcinoma (1), and mesothelioma (1). Therefore, 87 patients diagnosed as having bronchioloalveolar carcinoma in a pathology department of an American teaching hospital were available for the present analysis. Most diagnoses were based on light microscopy. In addition, we abstracted clinical and radiological characteristics from medical charts for all cases.

To determine whether bronchioloalveolar carcinoma is a tobacco related disease, we compared the smoking histories of the cases with those of hospital patients admitted for conditions not known to be aetiologically related to tobacco. The rationale was that smoking histories of cases and controls had to be similar if bronchioloalveolar carcinoma was not related to tobacco. Controls were therefore selected among patients on the American Health Foundation database who were free of cancers of the oropharynx, larynx, oesophagus, liver, kidney, or bladder and who had not had a myocardial infarction, emphysema, or chronic bronchitis. We attempted to find three controls with a non-cancer diagnosis and three controls with a cancer diagnosis for each of the original 107 cases, matched to the cases on sex, race (non-white $v$ white), age (within three years), hospital of admission, and date of interview (within two years). Of the 583 controls, 297 had cancer: gastrointestinal, $102(34 \%)$; prostate, 29 (10\%); lymphoma 22 (7\%); sarcoma, $10(3 \%)$; leukaemia and myeloma, $20(7 \%)$; breast, ovary, and endometrium, 48 (16\%); skin, 34 (12\%); and other, 32 (11\%). Discharge diagnoses of the 286 non-cancer controls included musculoskeletal $(34 ; 12 \%)$, benign

TABLE I-Sociodemographic characteristics of patients with bronchioloalveolar cancer and controls

\begin{tabular}{|c|c|c|c|}
\hline \multirow[b]{2}{*}{ Characteristics } & \multirow[b]{2}{*}{$\begin{array}{l}\text { Cases } \\
(\mathbf{n}=87)\end{array}$} & \multicolumn{2}{|c|}{ Controls } \\
\hline & & $\begin{array}{l}\text { Non-cancer } \\
(n=286)\end{array}$ & $\begin{array}{c}\text { Cancer } \\
(\mathrm{n}=297)\end{array}$ \\
\hline No (\%) women & $39(44 \cdot 8)$ & $169(45 \cdot 8)$ & $168(44 \cdot 8)$ \\
\hline No $(\%)$ non-whites & $5(5 \cdot 7)$ & $11(3 \cdot 4)$ & $16(5 \cdot 4)$ \\
\hline Mean (SD) age (years) & $61 \cdot 1(9 \cdot 8)$ & $60 \cdot 4(8 \cdot 9)$ & $60 \cdot 5(9 \cdot 2)$ \\
\hline Mean (SD) years of education & $12 \cdot 9(3 \cdot 3)$ & $13 \cdot 2(3 \cdot 5)$ & $13 \cdot 2(4 \cdot 0)$ \\
\hline Mean (SD) weight $(\mathrm{kg})$ & $71 \cdot 9(15 \cdot 5)$ & $74 \cdot 6(14 \cdot 2)$ & $73.6(12.9)$ \\
\hline Mean $(\mathrm{SD})$ height $(\mathrm{cm})$ & $168 \cdot 2(9 \cdot 3)$ & $169 \cdot 0(9 \cdot 5)$ & $168 \cdot 8(9 \cdot 9)$ \\
\hline
\end{tabular}

neoplastic $(104 ; 36 \%)$, infectious $(23 ; 8 \%)$, and other $(125 ; 44 \%)$ diseases.

Information was collected from the study participants with a structured and standardised questionnaire administered by trained interviewers. Interviewers were not aware whether the patients were cases or controls. Subjects who reported never having smoked regularly (that is, at least one cigarette per day for one year) were defined as never smokers. Smokers were asked to describe, in chronological order, the amount and duration of smoking of each brand of cigarette smoked during their lifetime. Summing all cigarettes smoked during the lifetime gave the total number of cigarettes smoked; dividing this variable by the total duration of smoking (in days) yielded the average number of cigarettes smoked per day.

Unconditional logistic regression was used to estimate the relative risk of bronchioloalveolar carcinoma and the 95\% confidence interval. ${ }^{.1}$ Since the conditional and the unconditional logistic regression analysis of matched data yield similar results when the unconditional logistic regression models include the matching factors as confounding variables, simultaneous adjustment was done for sex, age at diagnosis $(\leqslant 44,45-54,55-64,65-74, \geqslant 75)$, geographical area (New York City, Long Island, Chicago, Philadelphia), year of admission (1977-9, 1980-4, 1985-9), and race (white, non-white). Only age and sex were found to affect the studied association and were retained in the final model. Departure from the assumptions of the logistic regression model was checked by tabulating the observed and expected numbers of cases in each stratum for which a relative odds were computed." Analyses were first performed separately with the noncancer and the cancer controls and then with a pooled control group. Results of both analyses are presented.

\section{Results}

Table I shows that sociodemographic and clinical characteristics of cases and controls were similar. As in other published case series, there was no major difference in clinical presentation between male and female cases. ${ }^{2371213}$ Table II shows that bronchioloalveolar carcinoma had usually been diagnosed on routine chest $x$ ray in patients without respiratory symptoms and showed well defined or ill defined isolated radiological lesions of the upper lung; most patients were treated by surgery.

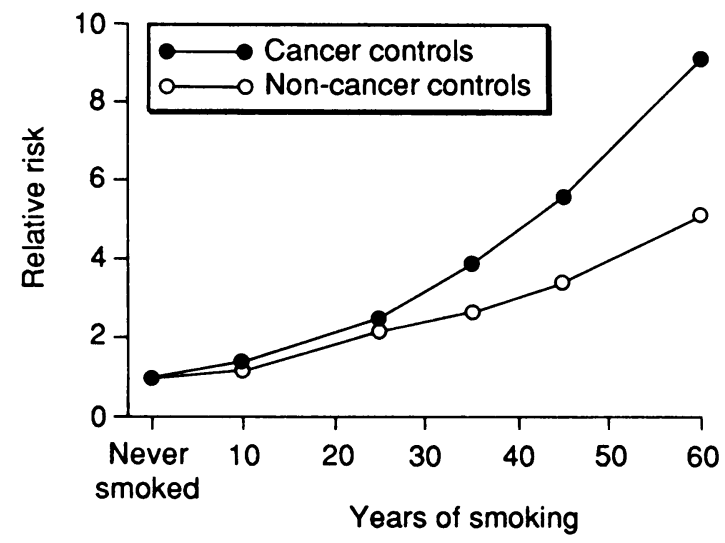

Relative risk estimates of bronchioloalveolar carcinoma related to years of cigarette smoking for 87 cases compared with 297 cancer controls and 286 non-cancer controls. Reference category is "never smokers"

Four out of 48 male cases (8\%) and 11 out of 39 female cases (28\%) had never smoked. Table III shows that the relative risks of bronchioloalveolar carcinoma increased with younger age at start of smoking and with longer duration of smoking (figure) and with intensity of smoking (average number of cigarettes per day) but decreased after smoking cessation. Similar trends were observed with both cancer and non-cancer controls, although relative risks were always higher with cancer controls. The inverse relation between bronchioloalveolar carcinoma and age at start of smoking was not significant when the non-cancer control group was used for comparison.

We assessed whether the association of smoking and bronchioloalveolar carcinoma differed between men and women or between age groups by adding a product term between sex or age and the continuous smoking related variables. None of these interaction terms were significant at the $10 \%$ level, suggesting that sex and age were pure confounding factors. However, the present study had low statistical power to detect interaction.

\section{Discussion}

In this first case-control study of the association between bronchioloalveolar carcinoma and cigarette smoking, relative risks (as estimated by the relative odds) were greater for subjects who started smoking at a younger age, smoked for a longer time, or smoked
«Patients may have had more than one symptom.

both. 
TABLE III - Estimated relative risks of bronchioloalveolar carcinoma related to smoking

\begin{tabular}{|c|c|c|c|c|c|c|}
\hline & \multirow{2}{*}{$\begin{array}{c}\text { No }(\%) \text { of } \\
\text { cases } \\
(n=87)\end{array}$} & \multicolumn{2}{|c|}{ No $(\%)$ of controls } & \multicolumn{3}{|c|}{ Adjusted relative risk ${ }^{\star}$ ( $95 \%$ confidence interval) } \\
\hline & & $\begin{array}{c}\text { Non-cancer } \\
(n=286)\end{array}$ & $\begin{array}{c}\text { Cancer } \\
(\mathbf{n}=297)\end{array}$ & $\begin{array}{l}\text { Non-cancer } \\
\text { controls }\end{array}$ & $\begin{array}{l}\text { Cancer } \\
\text { controls }\end{array}$ & $\begin{array}{c}\text { All } \\
\text { controls }\end{array}$ \\
\hline \multicolumn{6}{|l|}{ Never smokers } & $1 \cdot 0$ \\
\hline \multicolumn{7}{|c|}{ Age at start of smoking: } \\
\hline $20-50$ & $21(24)$ & $64(22)$ & $77(26)$ & $2 \cdot 3(1 \cdot 1$ to $4 \cdot 9)$ & $2 \cdot 4(1 \cdot 2$ to $5 \cdot 1)$ & $2 \cdot 3(1 \cdot 2$ to $4 \cdot 7)$ \\
\hline $17-19$ & $22(25)$ & $71(25)$ & $48(16)$ & $2 \cdot 1(1 \cdot 0$ to $4 \cdot 4)$ & $4 \cdot 1(1.9$ to 8.7$)$ & $2.9(1.4$ to 5.9$)$ \\
\hline $15-16$ & $20(23)$ & $26(9)$ & $36(12)$ & $5.7(2 \cdot 5$ to 12.9$)$ & $5 \cdot 2(2 \cdot 3$ to $11 \cdot 3)$ & $5 \cdot 3(2 \cdot 5$ to $11 \cdot 2)$ \\
\hline $10-14$ & $9(10)$ & $28(10)$ & $14(5)$ & $2 \cdot 3(0.9$ to 6.2$)$ & $6 \cdot 0(2 \cdot 1$ to $17 \cdot 3)$ & $3.6(1.4$ to 9.2$)$ \\
\hline$\chi^{2}$ for trend $(\mathrm{df}=1)$ & & & & & & \\
\hline \multirow{2}{*}{\multicolumn{7}{|c|}{ Years of smoking: }} \\
\hline & & & & & & \\
\hline $1-19$ & $7(8)$ & $40(14)$ & $42(14)$ & $1.2(0.5$ to 3.3$)$ & $1.4(0.5$ to 3.9$)$ & $1.3(0.5$ to 3.5$)$ \\
\hline $20-29$ & $12(14)$ & $38(13)$ & $40(14)$ & $2 \cdot 2(0.9$ to 5.3$)$ & $2 \cdot 5(1 \cdot 1$ to 6.0$)$ & $2.4(1.0$ to 5.4$)$ \\
\hline $30-39$ & $25(29)$ & $60(21)$ & $52(18)$ & $2 \cdot 7(1 \cdot 3$ to $5 \cdot 7)$ & $3.9(1.9$ to $8 \cdot 1)$ & $3.3(1.6$ to 6.5$)$ \\
\hline $40-49$ & $16(18)$ & $34(12)$ & $28(9)$ & $3.4(1.5$ to 5.8$)$ & $5 \cdot 6(2 \cdot 4$ to $13 \cdot 3)$ & $4 \cdot 3(2.0$ to $9 \cdot 5)$ \\
\hline $50-80$ & $12(14)$ & $17(6)$ & $13(4)$ & $5 \cdot 1(1.9$ to 13.5$)$ & $9 \cdot 1(3 \cdot 3$ to $25 \cdot 2)$ & $6 \cdot 9(2 \cdot 7$ to $17 \cdot 2)$ \\
\hline$\chi^{2}$ for trend $(\mathrm{df}=1)$ & & & & & & $25 \cdot 0$ \\
\hline p Value & & & & & & $<0.001$ \\
\hline \multicolumn{7}{|c|}{ Average No of cigarettes per day: } \\
\hline $1-19$ & $17(20)$ & $77(27)$ & $77(26)$ & $1.5(0.7$ to 3.3$)$ & $1.9(0.9$ to 4.0$)$ & $1.7(0.8$ to 3.6$)$ \\
\hline $20-29$ & $28(32)$ & $64(22)$ & $57(19)$ & $3.3(1.6$ to 6.9$)$ & $4 \cdot 6(2 \cdot 2$ to $9 \cdot 4)$ & $3.9(2.0$ to $7 \cdot 7)$ \\
\hline $30-39$ & $12(14)$ & $23(8)$ & $18(6)$ & $4 \cdot 1(1.6$ to 10.3$)$ & $6 \cdot 7(2 \cdot 6$ to $17 \cdot 3)$ & $5 \cdot 1(2 \cdot 2$ to $12 \cdot 0)$ \\
\hline $40-80$ & $15(17)$ & $25(9)$ & $23(8)$ & $5.0(2.0$ to 12.5$)$ & $7 \cdot 6(3 \cdot 1$ to $19 \cdot 0)$ & $6.0(2.6$ to 14.0$)$ \\
\hline$\chi^{2}$ for trend $(\mathrm{df}=1)$ & & & & & & $26 \cdot 0$ \\
\hline \multicolumn{7}{|c|}{ Years stopped smoking: } \\
\hline Current smoker & $36(42)$ & $89(31)$ & $69(23)$ & $3.7(1.6$ to 8.8$)$ & $2 \cdot 3(1.0$ to 5.2$)$ & $3.9(1.8$ to 8.7$)$ \\
\hline $1-9$ & $14(16)$ & $26(9)$ & $30(10)$ & $2.9(1.5$ to 5.9$)$ & $3 \cdot 8(2 \cdot 1$ to $7 \cdot 1)$ & $3.7(1.9$ to $7 \cdot 1)$ \\
\hline $10-19$ & $13(15)$ & $32(11)$ & $37(13)$ & $2 \cdot 6(1 \cdot 1$ to $6 \cdot 1)$ & $2 \cdot 1(0.9$ to 4.9$)$ & $2 \cdot 7(1 \cdot 2$ to $6 \cdot 1)$ \\
\hline & $9(10)$ & $42(15)$ & $39(13)$ & $1.5(0.6$ to 3.7$)$ & $1.5(0.6$ to 4.0$)$ & $1.7(0.7$ to 4.0$)$ \\
\hline \multirow{2}{*}{\multicolumn{2}{|c|}{$\begin{array}{l}\chi^{2} \text { for trend }(\mathrm{df}=1) \\
\mathrm{p} \text { Value }\end{array}$}} & & & & & 18.4 \\
\hline & & & & & & $<0.001$ \\
\hline
\end{tabular}

${ }^{\star}$ Estimated by relative odds and simultaneously adjusted for age and sex.
Previous published reports do not contradict the hypothesis that bronchioloalveolar carcinoma is a tobacco related disease. The reported proportions of never smokers in bronchioloalveolar carcinoma patients vary from $10 \%$ to $30 \%^{3467}$; they are higher than in adenocarcinoma $(5-16 \%)^{3468}$ or squamous cell or small or oat cell carcinoma $(0-5 \%){ }^{368}$ Still, the proportion of never smokers in lung cancer patients of any cell type, including bronchioloalveolar carcinoma, is lower than that in the general United States population in $1980-3$ (34\% of men, $55 \%$ of women). ${ }^{20}$ These data suggest that smoking has a role in the aetiology of all lung cancers even though there is evidence that smoking may be a weaker cause for more peripheral cell types. ${ }^{8}$

In summary, $10 \%$ of men and $25 \%$ of women with bronchioloalveolar carcinoma in this study had never smoked cigarettes. Active smoking cannot therefore be the only factor in the aetiology of the disease. Nevertheless, we show strong evidence that, for a majority of cases, smoking may be causally related to bronchioloalveolar carcinoma.

We acknowledge the valuable contribution of the following cooperating institutions and individuals: Loyola University Medical Center (Chicago), Dr Edward R Yarrity Jr; Long Island Jewish Hospital (New York), Dr Kanti R Rai; Nassau County Medical Center, Dr Linga Raju; Memorial Hospital Sloane-Kettering (New York), Drs David Schottenfeld and Nael Martini; Thomas Jefferson University Hospital (Philadelphia), Dr Paul Stolley. We also thank the interviewers, Rita Decker, Belle Hecht, Lisa Ramos, Sally Wetzler, Nancy Deir, Talia Donnenberg, and Janet Smith; Cheun-Lan Liang for programming assistance; Marion Moore for supervision of data collection; Maryline Primus for manuscript preparation; and $\mathrm{Dr} \mathrm{Ph}$ Nicod for his thoughtful comments. were above $5 \cdot 0$, with a lower $95 \%$ confidence limit at about $2 \cdot 0$. There were significant dose-response relations between risk of bronchioloalveolar carcinoma and either age at start of smoking, years of smoking, average number of cigarettes per day, or years of smoking cessation. Except for age at start of smoking, findings were consistent when two different types of controls, including one group of patients with cancer diagnoses, were used. Relative risks were always higher with cancer controls than with non-cancer controls. This is due to the higher proportion of smokers in patients admitted with non-neoplastic diseases.

That these findings result from misclassification of adenocarcinoma or other known, tobacco related lung cancer cell types can be reasonably ruled out. Histological diagnoses were based on abundant material: more than $85 \%$ of the cases had lobectomy or pneumonectomy. In addition, these diagnoses are highly likely to be reliable: Feinstein et al found only $2 \%$ disagreement when five experienced pathologists read slides of well differentiated carcinoma. ${ }^{12}$ Diagnoses of well differentiated lung cancers are quite reproducible. ${ }^{1314}$

Ultrastructural analyses suggest that bronchioloalveolar carcinoma originates either from alveolar cells (pneumonocytes of type II) or from bronchiolar cells (Clara cells, or metaplastic mucus secreting cells). ${ }^{215} 16$ It is therefore biologically plausible for smoking to be carcinogenic for bronchiolar or alveolar cells, since tobacco smoke is known to reach the most distal respiratory airways ${ }^{17}$ and induce an inflammatory state with an increased number of alveolar macrophages. ${ }^{18}$ The release of free oxygen radicals and of proteolytic enzymes may enhance the action of the numerous carcinogens and cocarcinogens contained in tobacco smoke. ${ }^{19}$
1 Liebow AA. Bronchiolo-alveolar carcinoma. Adv Intern Med 1960;10:329-58. 2 Clayton $F$. The spectrum and significance of bronchioloalveolar carcinomas. Pathol Annu 1988;23:361-94.

3 Schraufnagel D, Peloquin A, Pare JAP, Wang NS. Differentiating bronchiolo4 Grover FL, Piantadosi S, The Lung Cancer Study Group. Recurrence and survival following resection of bronchioloalveolar carcinoma of the lung: The Lung Cancer Study Group experience. Ann Surg 1989;209:779-90.

5 Rosenow EC III, Carr DT. Bronchogenic carcinoma. CA 1979;29:233-45.

6 Vincent RG, Pickren JW, Lane WW, Bross I, Takita H, Houten L, et al. The changing histopathology of lung cancer: a review of 1682 cases. Cancer 1977;39:1647-55.

7 Greco RJ, Steiner RM, Goldman S, Cotler H, Patchefsky A, Cohn HE. Bronchoalveolar cell carcinoma of the lung. Ann Thorac Surg 1986;41:652-6.

8 Morabia A, Wynder EL. Cigarette smoking and lung cancer cell types. Cancer 1991;68:2074-8.

9 Geddes DM. Bronchioloalveolar carcinoma. BMf 1987;294:3

10 Wynder EL, Stellman SD. Comparative epidemiology of tobacco-related cancers. Cancer Res 1977;37:4608-22.

11 Breslow NE, Day NE. Statistical methods in cancer research. Vol 1. The analysis of case-control studies. Lyons: International Agency for Research on Cancer, 1980.

12 Feinstein AR, Gelfman NA, Tesner R, Averbach O, Hackel DB, Pratt PC. Observer variability in the histopathologic diagnosis of lung cancer. Am Rev Respir Dis 1970;101:671-84.

13 Stanley KE, Matthews MJ. Analysis of a pathology review of patients with lung tumors. INCI 1981;66:989-92.

14 Ives JC, Buffer PA, Greenberg SD. Environmental associations and histopathologic patterns of carcinoma of the lung: the challenge and dilemma in epidemiologic studies. Am Rev Respir Dis 1983;128:195-209.

15 Edwards CW. Alveolar carcinoma: a review. Thorax 1984;39:166-74.

16 Manning JT Jr, Spjut HJ, Tschen JA. Bronchioloalveolar carcinoma: the significance of two histopathologic types. Cancer 1984;54:525-34.

17 Jones JL, Muity BD, Lawler P, Hulands G, Growlet JCW, Veall N. Increased alveolar permeability in cigarette smokers. Lancet $1980 ; \mathrm{i} \cdot 66-8$.

18 Hoidal JR, Niewoehner DE. Lung phagocyte recruitment and metabolic alterations induced by cigarette smoke in humans and hamsters. Am Rev Respir Dis 1982;126:548-52.

19 Hoidal JR, Foy RB, LeMarbe PA, Perri R, Repine SE. Altered oxidative metabolic responses in vitro of alveolar macrophages from asymptomatic

20 National Center for Health Statistics, Division of Health Interview Statistics. Data from the national health interview study. Washington, DC: NCHS, 1984.

(Accepted 4 December 1991) alveolar carcinoma from adenocarcinoma. Am Rev Respir Dis 1982;15:74-9. cigarette smokers. Am Rev Respir Dis 1981:123:85-9. 